\title{
Large Scale Pullout Machine and Effectiveness of Anchor Block in Stabilising Reinforced Earth Wall under Wetting Condition
}

\author{
${ }^{1}$ Adnan Derahman, ${ }^{2}$ Mohd Jamaludin Md Noor, ${ }^{1}$ Zulhafizal Othman, \\ ${ }^{2}$ Nurul Aishah Abd Rahman and ${ }^{1}$ Muhammad Isha Ismail \\ ${ }^{1}$ Faculty of Civil Engineering, UiTM Pahang Branch, Jengka Campus, \\ 26400 Bandar Pusat Jengka, Pahang, Malaysia \\ ${ }^{2}$ Faculty of Civil Engineering, UiTM Shah Alam, 40450 Shah Alam, Selangor, Malaysia
}

\begin{abstract}
Failure in reinforced Earth wall system has been rampant, especially during wet season. The wetting due to infiltration from the ground surface or inundation of the GWT has an adverse effect to the strength interaction between the reinforcement system and the surrounding soil. This is due to the reduction in the shear strength upon the loss of suction when the soil condition changes from unsaturated to fully saturated condition. However, the mishap needs to be resolved by the geotechnical engineers. This study will present on the effectiveness of applying the anchor block at the free end of the reinforcement when the system is wetted. The pullout test has been conducted in a large scale pullout apparatus of dimensions; $2 \mathrm{~m}$ length by $1 \mathrm{~m}$ width and depth of $1 \mathrm{~m}$. The reinforcement is made up of mild steel reinforcement rod of diameter $33 \mathrm{~mm}$ and length of $1.5 \mathrm{~m}$. The anchor block is made of concrete with dimensions of $200-200 \mathrm{~mm}$ and thickness of $100 \mathrm{~mm}$. The pullout tests were conducted at various effective and net stresses and initially the strength of the test sand at various effective and net stresses were determined. The results showed that there was a massive increase in the pullout strength when the anchor block was applied and there was a less effect on the drop of the pullout strength upon wetting with the application of the anchor block compared to the non-anchored system.
\end{abstract}

Key words: Shear strength, suction, unsaturated and saturated condition, pullout strength, reinforcement, anchor block

\section{INTRODUCTION}

Retaining structures such as retaining walls, basement walls and bulkheads are commonly encountered in foundation engineering and they may support slopes of Earth mass. Proper design and construction of these structures require a thorough knowledge of the lateral forces that act between the retaining structures and the soil mass being retained. Reinforced Earth wall is types of wall where soil is compacted to hold the reinforcing strips. The concrete wall is made of interlocking concrete blocks of various shape and sizes. The reinforced Earth wall is typically found in a highway construction and it used to stabilization of slopes. There have been many cases of wall failure by bulging. Figure 1 shows the potential causes of this type of wall failure are might due to the over estimate the shear strength at the lower part of wall, the influence of a hydrostatic pressure at lower part of the retaining wall and the soil in the retaining wall transformed from unsaturated to saturated condition. One of the stability criteria of reinforced Earth wall is stability against

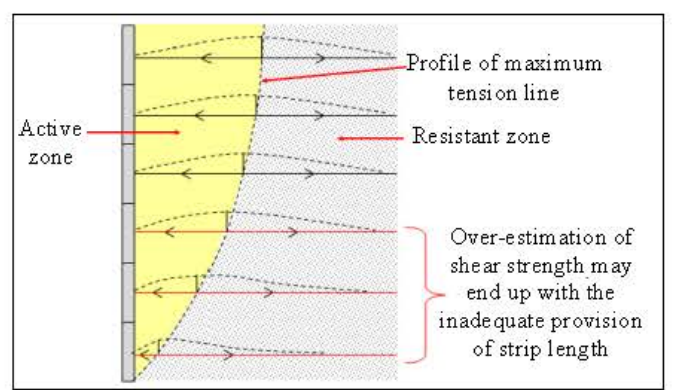

Fig. 1: Strip length outside the active zone provides the friction against wall movement

wall bulging which can be due to strip breakage or slippage. Strip breakage can be avoided by providing adequate cross-sectional area while the strip slippage is governed by the coefficient of friction, $\mu$ and the contact area between the soil and the strip.

The following photographs illustrate typical lower part of wall failures which have been published at the

Corresponding Author: Adnan Derahman, Faculty of Civil Engineering, UiTM Pahang Branch, Jengka Campus, 


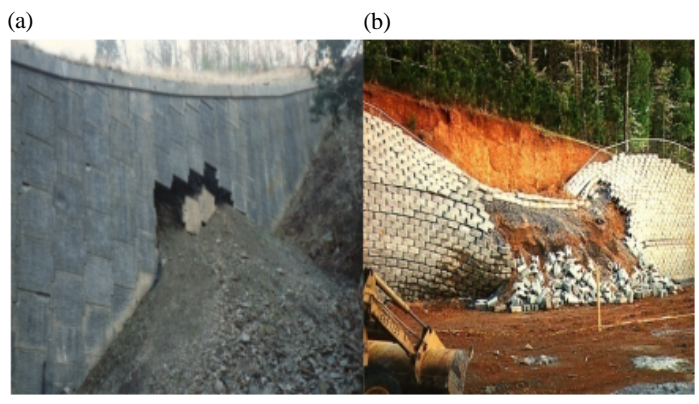

Fig. 2: Typical failures of reinforced Earth structures

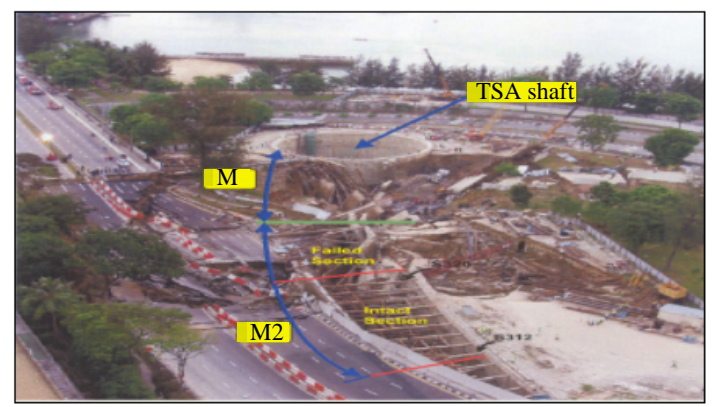

Fig. 3: The collapse of Nicoll Highway, Singapore on 20th April 2004. (Proc. 16th South East Asian Geotechnical Conference)

international symposium on reinforced soil held in Dresden, Germany during September 2004 as shown in Fig. 2 (Mak and Lo, 2001). The coefficient of friction is taken as a function of the soil internal friction angle $\varnothing^{\prime}$. Besides, the active force acting on the wall which determine the tension on each strip is calculated base on the vertical stress and the coefficient of active pressure, $\mathrm{K}_{\mathrm{a}}$ which is also obtained base on internal friction angle, $\oslash$. Therefore the strip length is designed base on the internal friction angle, $\varnothing^{\prime}$.

Figure 3 shows the collapse of Nicoll Highway, Singapore on 20th April 2004 which has been reported due to the over-estimating of shear strength at high effective stress (Baharom and Hamzah, 2005).

The present practice considers this angle as constant irrespective of the effective stress. In other words it is applying the Terzaghi (1936) shear strength model which considers a linear variation of shear strength relative to effective stress, i.e., a single value of $\varnothing^{\prime}$. When the real behaviour of shear strength relative to effective stress is non-linear for granular back filled soils then the design shear strength at soil greater depth will be over-estimated as illustrated in Fig. 4.

Since, this is the common material used for backfill material in retaining structures it may end up with the

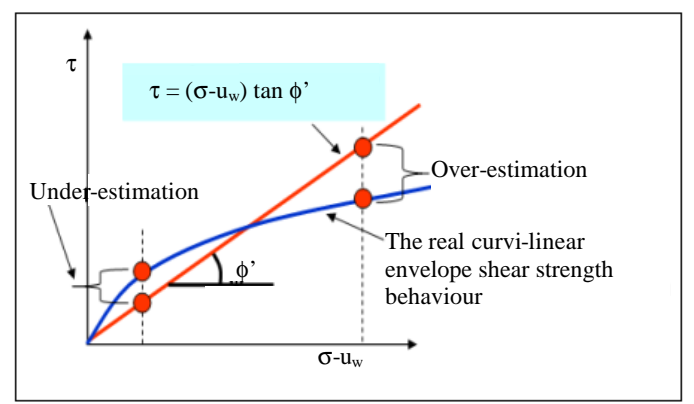

Fig. 4: Terzaghi (1936)'s shear strength model against the real curvi-linear envelope shear strength behaviour

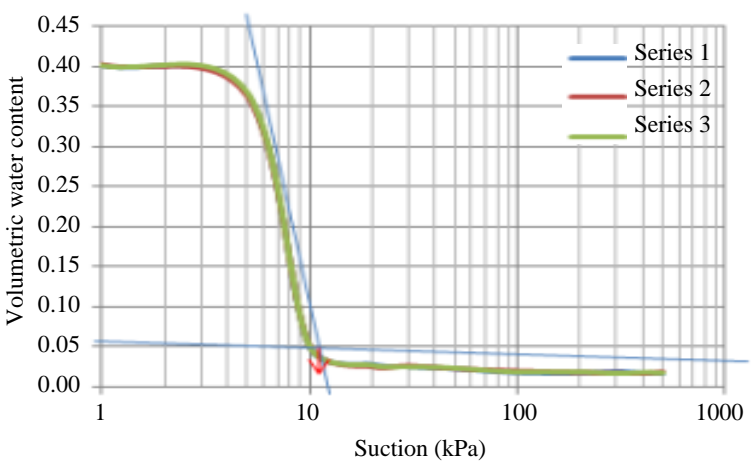

Fig. 5: Soil water characteristic curve base on volumetric water content; Residual suction at $10 \mathrm{kPa}$

Table 1: Result from dry sieve analysis

\begin{tabular}{lccc}
\hline Particle size & Silt & Sand & Gravel \\
\hline Range of particles sizes (\%) & 0.02 & 99.655 & 0.325 \\
\hline
\end{tabular}

Soil classification: Uniformly graded sand

provision of inadequate strip length for the bottom reinforcing strips. This is anticipated to be the cause of wall bulging. This illustrates the importance of applying the right shear strength which can be achieved through the curved surface envelope shear strength model. This also gives the implication that the application of the curved surface envelope shear strength model will be more conservative than, the Terzaghi (1936) Model.

Characterising the properties of test material and the saturated and unsaturated shear strength:Dry sieving method test were used to characterize the soil classification. The soil particle size distributions were done and the particle size distribution spreadsheets created by Baharom and Hamzah (2005) were used in analyzing data of the study. Referring to the particle distribution analysis and according to british standard soil classification (BS8006, 1995) the sand which has been used in this study is classified as uniformly graded sand and the range of particle size distribution is shown in Table 1.

The graphical presentation of soil-water characteristic curve is shown in Fig. 5. Residual suction obtained from 


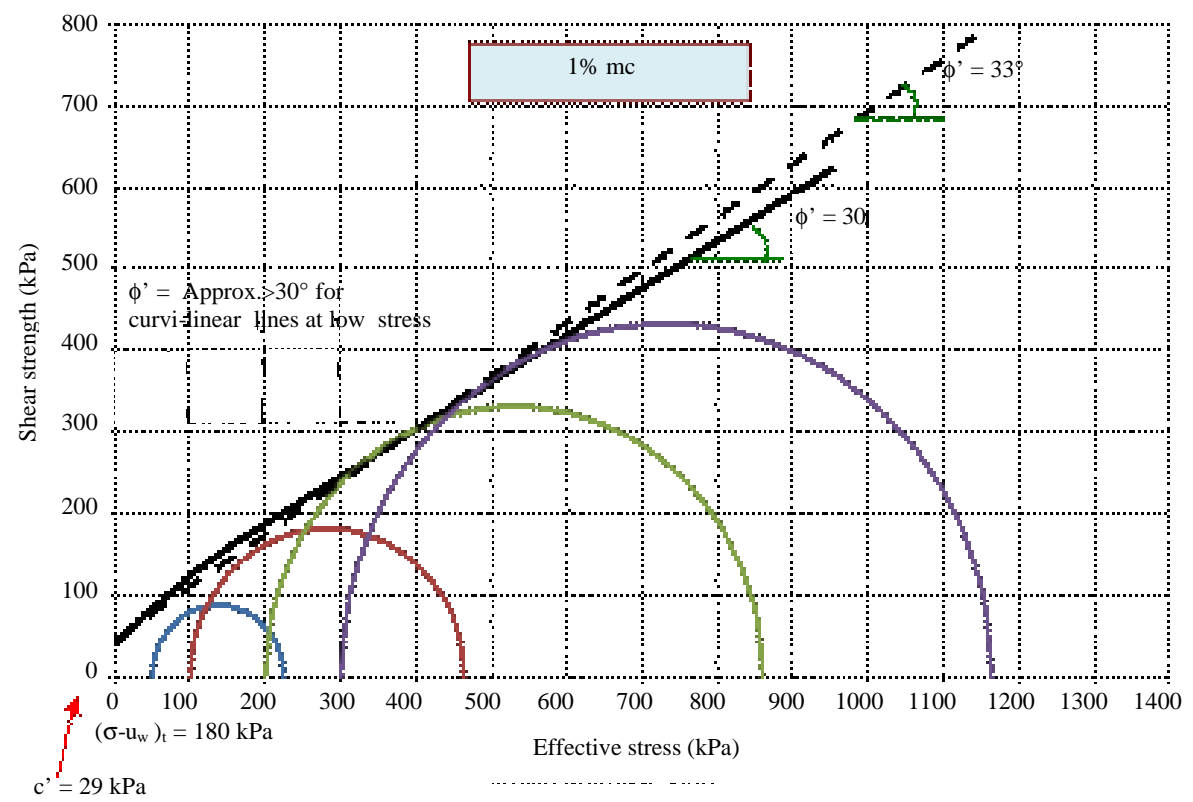

Fig. 6: Comparison between linear and curvi-linear envelope with $1 \%$ moisture content

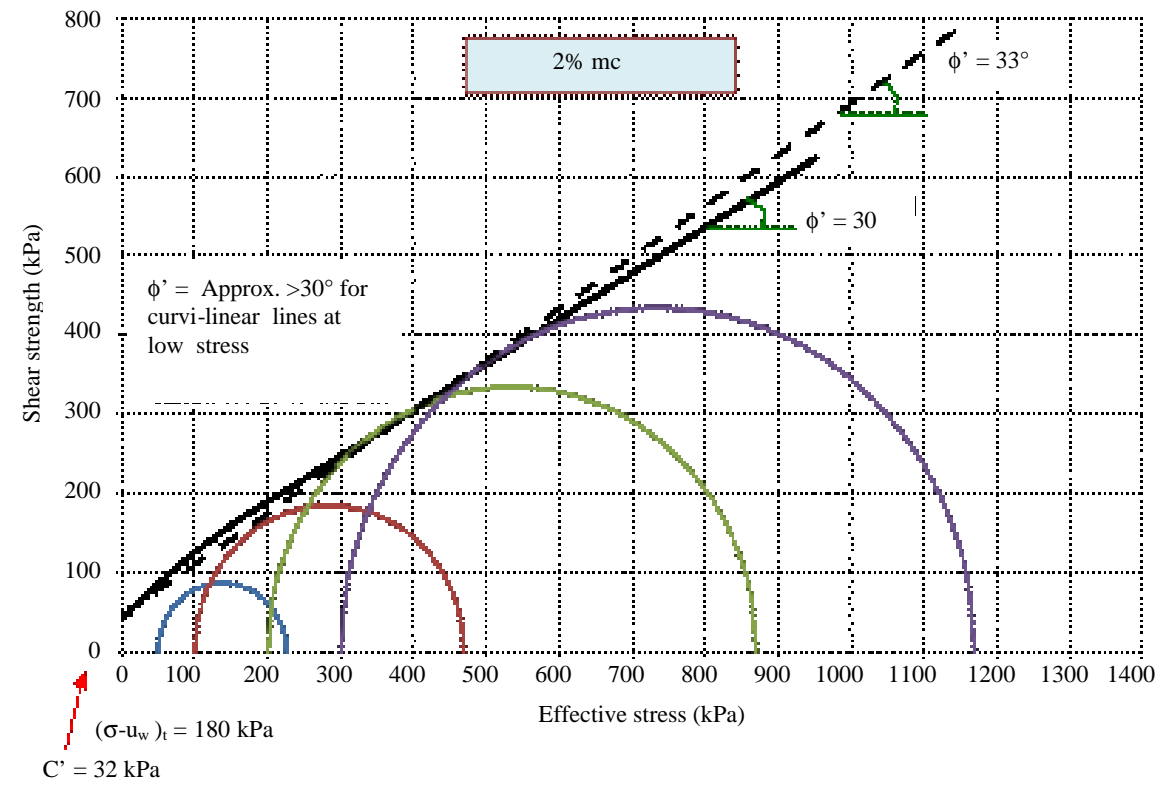

Fig. 7: Comparison between linear and curvi-linear envelope with $2 \%$ moisture content

soil-water characteristic curve plot from this study is in line with a typical soil-water characteristic curve which is introduced by Fredlund et al. (1997). The shear strength of the test sand has been characterizes using consolidated drained saturated tests in conventional triaxial cell and consolidated drained unsaturated tests using non-axis translation method in the same triaxial cell. The shear strength envelopes at failure for unsaturated CD triaxial tests at moisture contents of $1,2,6$ and $12 \%$ are shown in Fig. 6-9. Figure 10 shows the shear strength envelope at failure for saturated $\mathrm{CD}$ triaxial tests. Figure 11 shows the determined variation of apparent shear strength with respect to suction (Noor and Anderson, 2006). Apparently the shear strength increases non-linearly up to residual suction of $10 \mathrm{kPa}$ and start to decrease non-linearly beyond residual suction until the apparent shear strength is zero at ultimate suction of $70 \mathrm{kPa}$. 


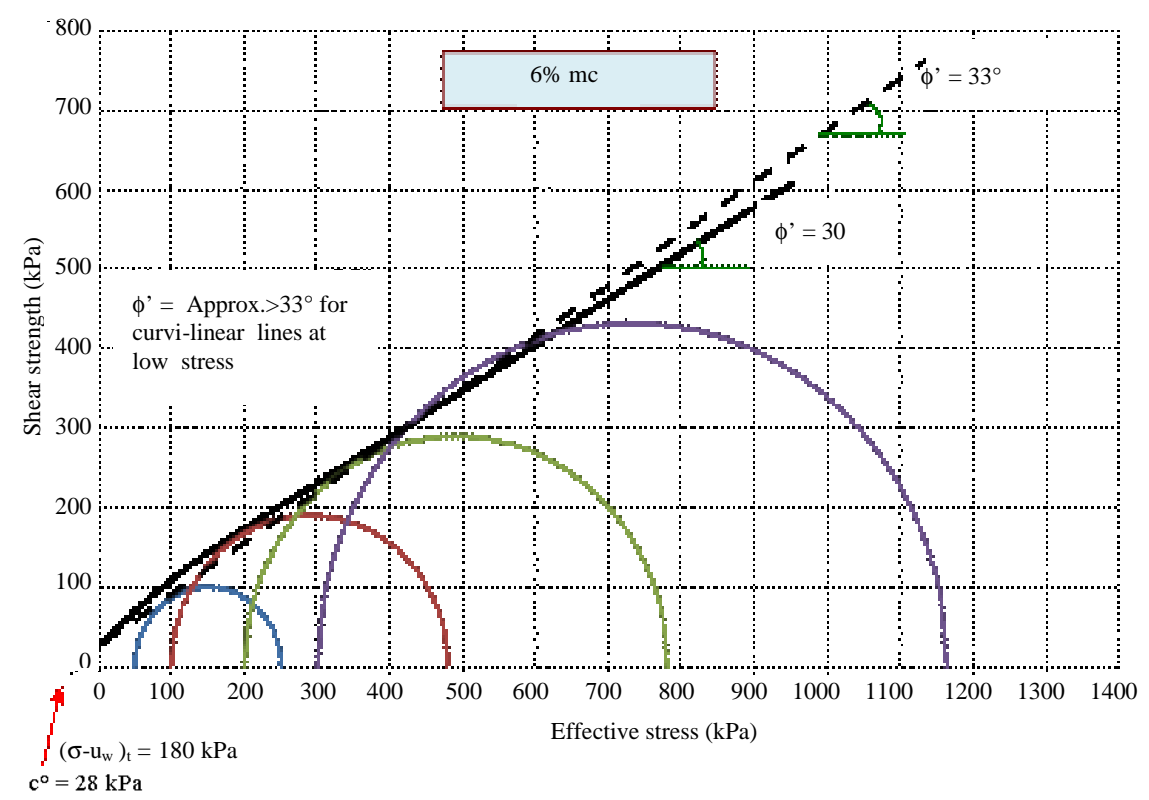

Fig. 8: Comparison between linear and curvi-linear envelope with $6 \%$ moisture content

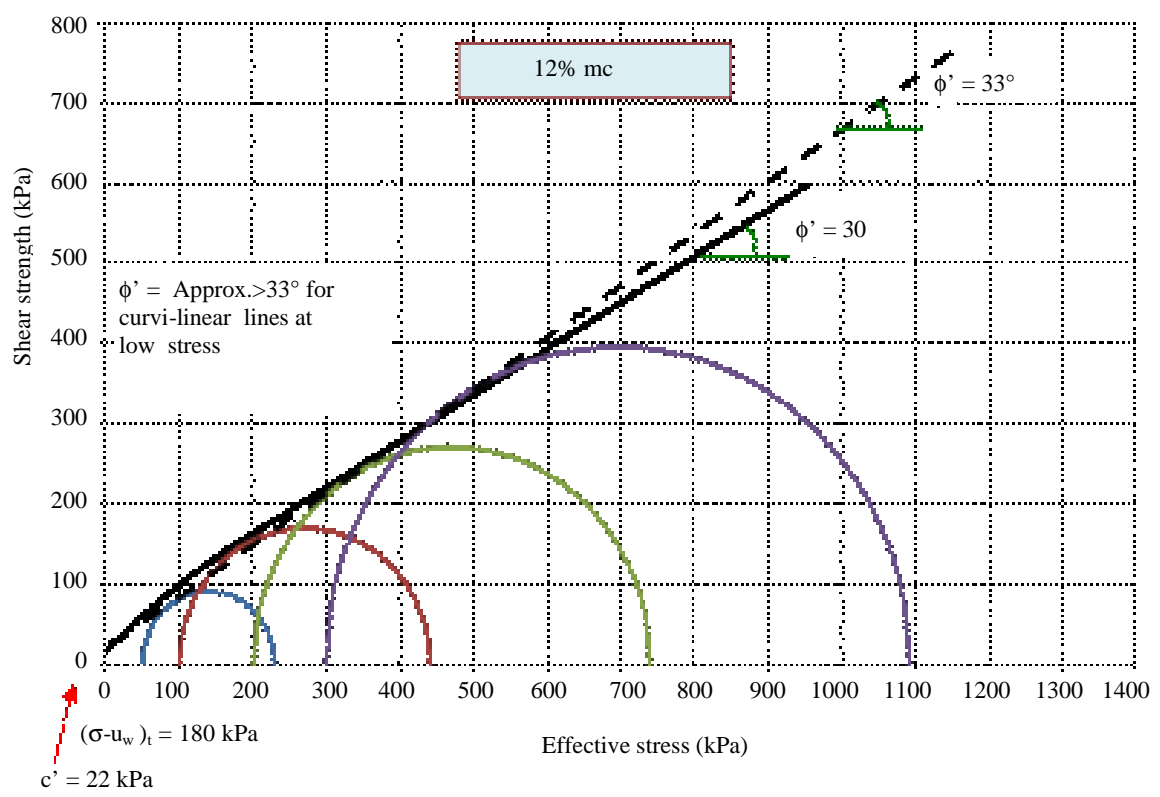

Fig. 9: Comparison between linear and curvi-linear envelope with $12 \%$ moisture content

Development of pullout apparatus: The pullout apparatus usage does not limited to this study only but it can be used for any other future research. This pullout apparatus was design in such a way that it is capable to test any type of reinforcement or backfill material at a full scale condition. The pullout apparatus was designed by the researchers and fabricated locally. A large scale pullout testing is considered to be a suitable method for studying reinforcement behaviour (Christopher et al., 1989; Mak and Lo, 2001). Many researchers have designed pullout boxes with typical dimensions ranging from a width of $0.6-1.0 \mathrm{~m}$ and length of $1.0-3.0 \mathrm{~m}$ (Lopes and Ladeira, 1996; Palmeria and Milligan, 1989).

Ghionna et al. (2001) suggests that the depth of the box should be $>40$ times the thickness of the reinforcement to avoid interference with the passive 


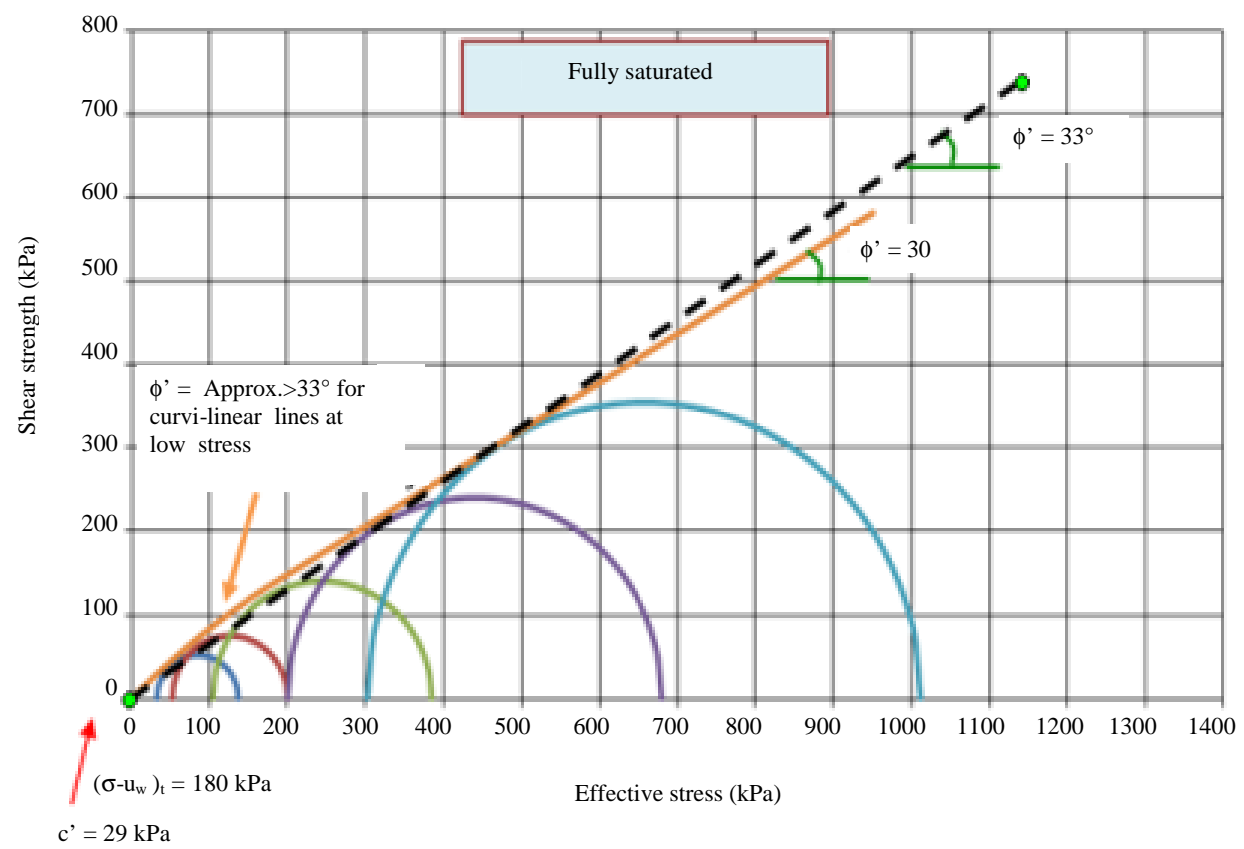

Fig. 10: Comparison between linear and curvi-linear envelope with fully saturated

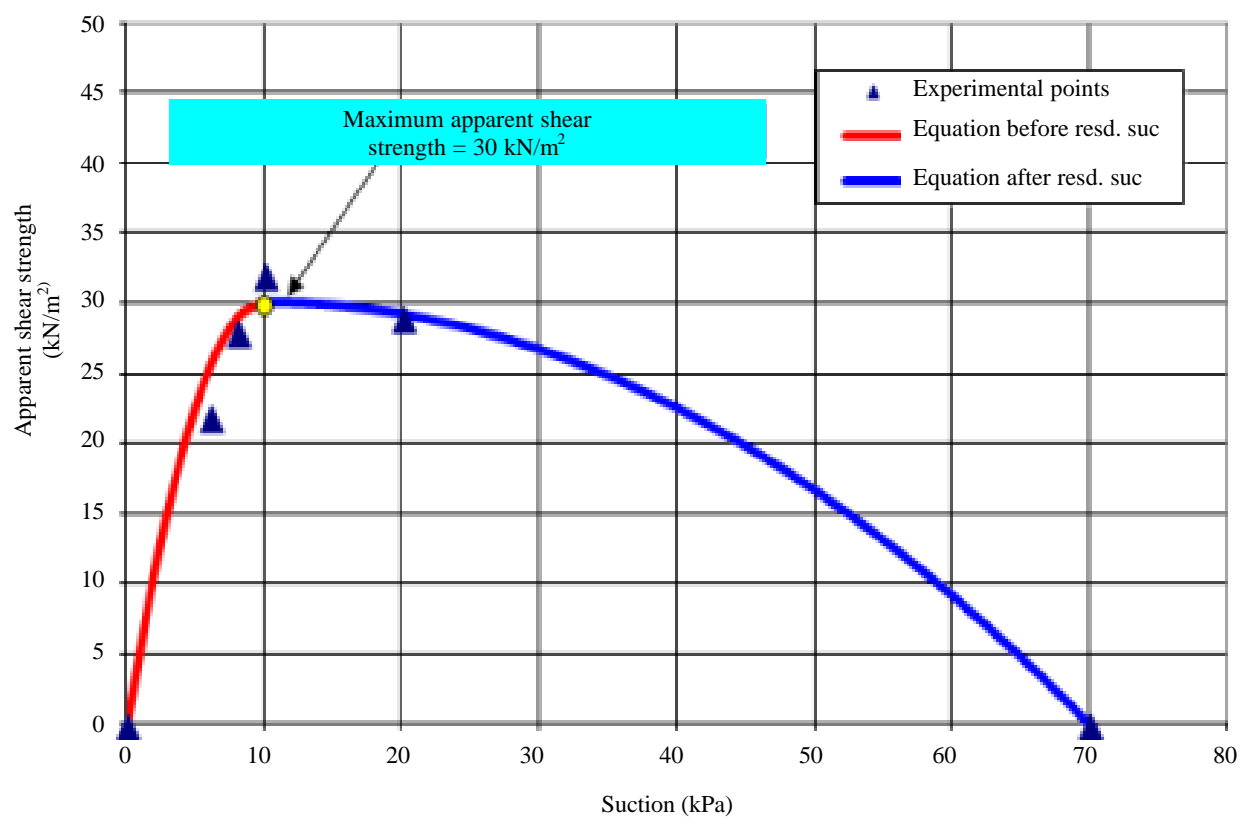

Fig. 11: The distribution of the experimental points relative to curved-surface envelope of $\mathrm{Md}$ (Noor and Anderson, 2006)

failure surface; However, examples vary from a depth of 0.17-0.64 m (Izawa et al., 2001; Ghionna et al., 2001). It is generally recognised that should the dimensions of the pullout box be too small relative to the reinforcement sample some interference from friction with the sides of the box can affect the soil-reinforcement interaction and therefore, affect the obtained results (Ghionna et al., 2001). The size of this pullout apparatus comply with design practice for calculation of reinforcement in reinforced Earth wall where the spacing applied is $1.0 \mathrm{~m}$. 


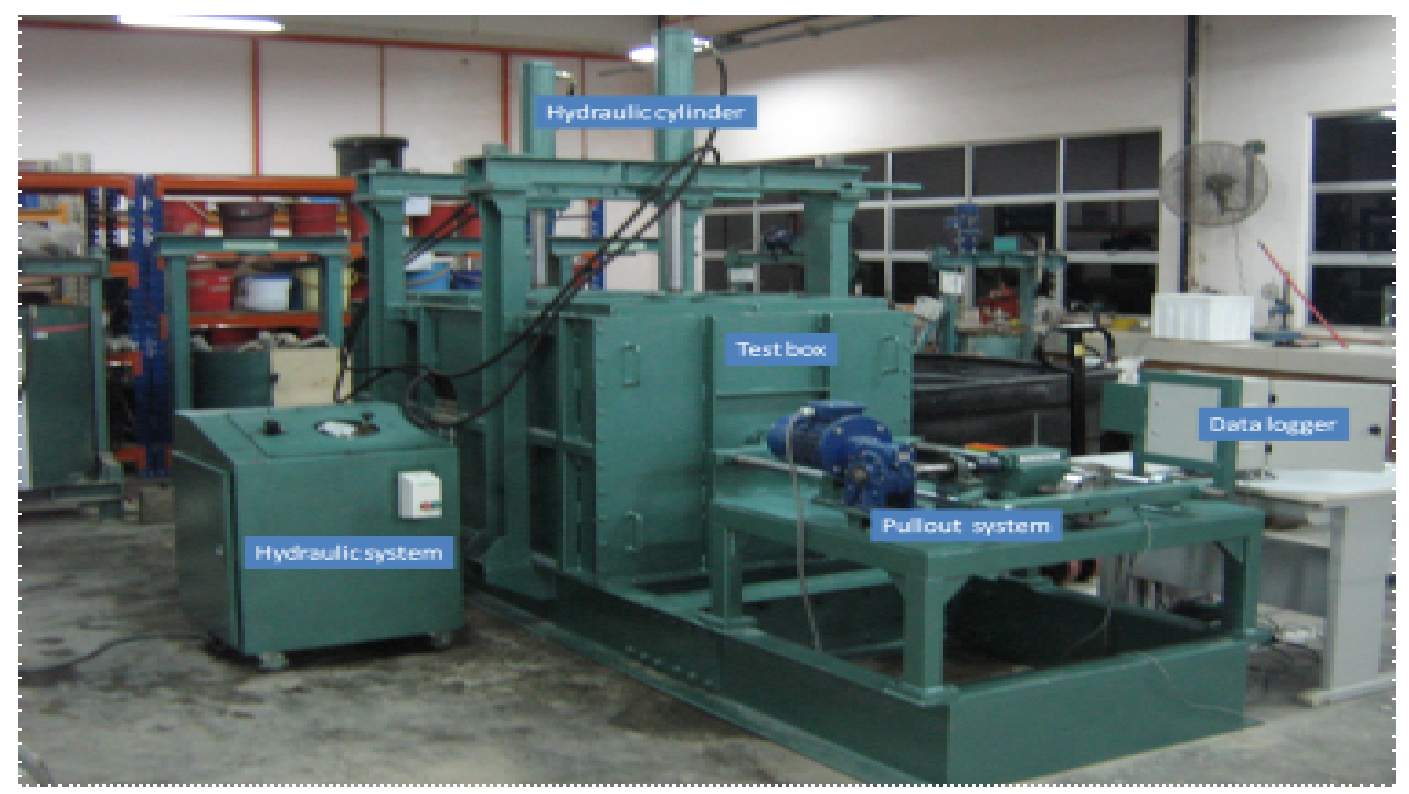

Fig. 12: Pullout apparatus with 3 major components

The idea to develop this pullout apparatus comes when the research decided to investigate the interaction between fill and reinforcement with a typical anchor block of $200 \times 200 \times 100 \mathrm{~mm}$ dimensions under various vertical pressure (effective/net stress) and various moisture content (suction) meanwhile at the same time to validate the maximum pullout force value by adopting the internal angle of friction which was based on the analysis from the curved-surface shear strength model into the equation (Noor and Anderson, 2006).

This pullout apparatus is different from any other typical pullout apparatus. The size of the pullout box is bigger compared with the others and furthermore it does not need to be mounted or anchored to the floor. Due to its large size and mounted on $90 \times 300 \mathrm{~mm}$ channels beams as a base together with the pulling system makes the self weight itself as a stable system and will not bend or being lifted up from the floor during the testing process. Another main advantage of this design is that it can be moved to any desired location.

The inverter which attached next to the data logger controls the speed of pullout from a minimum of $1-2 \mathrm{~mm} / \mathrm{min}$. It can be set to pull or to push the reinforcement from the pullout test box by setting forward or reverse button on the inverter control box. The data logging system is connected to a computer with installed software called Campbell scientific which compatible with the data logger. A standard displacement rate is 1 $\mathrm{mm} /$ minute according to previous researchers (Lee, 2003; Antonio, 2002; Hayashi et al., 1994). The pullout apparatus system are as shown in Fig. 12 consists of 3 major components which are test box, hydraulic system and pullout system.

\section{MATERIALS AND METHODS}

The pullout tests were performed to evaluate the behaviour of soil-reinforcement interactions under saturated and unsaturated conditions. The soil specimen which were filled and compacted by layers of approximately $10 \mathrm{~cm}$ thick compaction (Lee, 2003) in the pullout box with the present of anchor block attached to the far end of a steel rod were tested by a pulling out force horizontally towards out of the pullout box while loaded vertically with various vertical pressure (effective/net stress) and various moisture content (suction) of soil specimen (Lee, 2003). The schematic diagrams of a pullout test system are shown in Fig. 13. The horizontal pullout force was set to move by $1 \mathrm{~mm} / \mathrm{min}$ and the data logging capture the pullout force reading in $\mathrm{kN}$ from the load cell attached to the system and $200 \mathrm{~mm}$ LVDT attached to monitor the horizontal movements. A standard displacement rate is $1 \mathrm{~mm} / \mathrm{min}$ according to previous researchers (Lee, 2003; Antonio, 2002; Hayashi et al., 1994).

Vertical pressures imposed on the soil specimen were fixed to a certain loading according to the test scheduled. Seven series of test specimen with seven different moisture content of $0 \%$ (dry), 1, 2, 6 and $12 \%$, fully saturated and fully saturated without anchor block under 

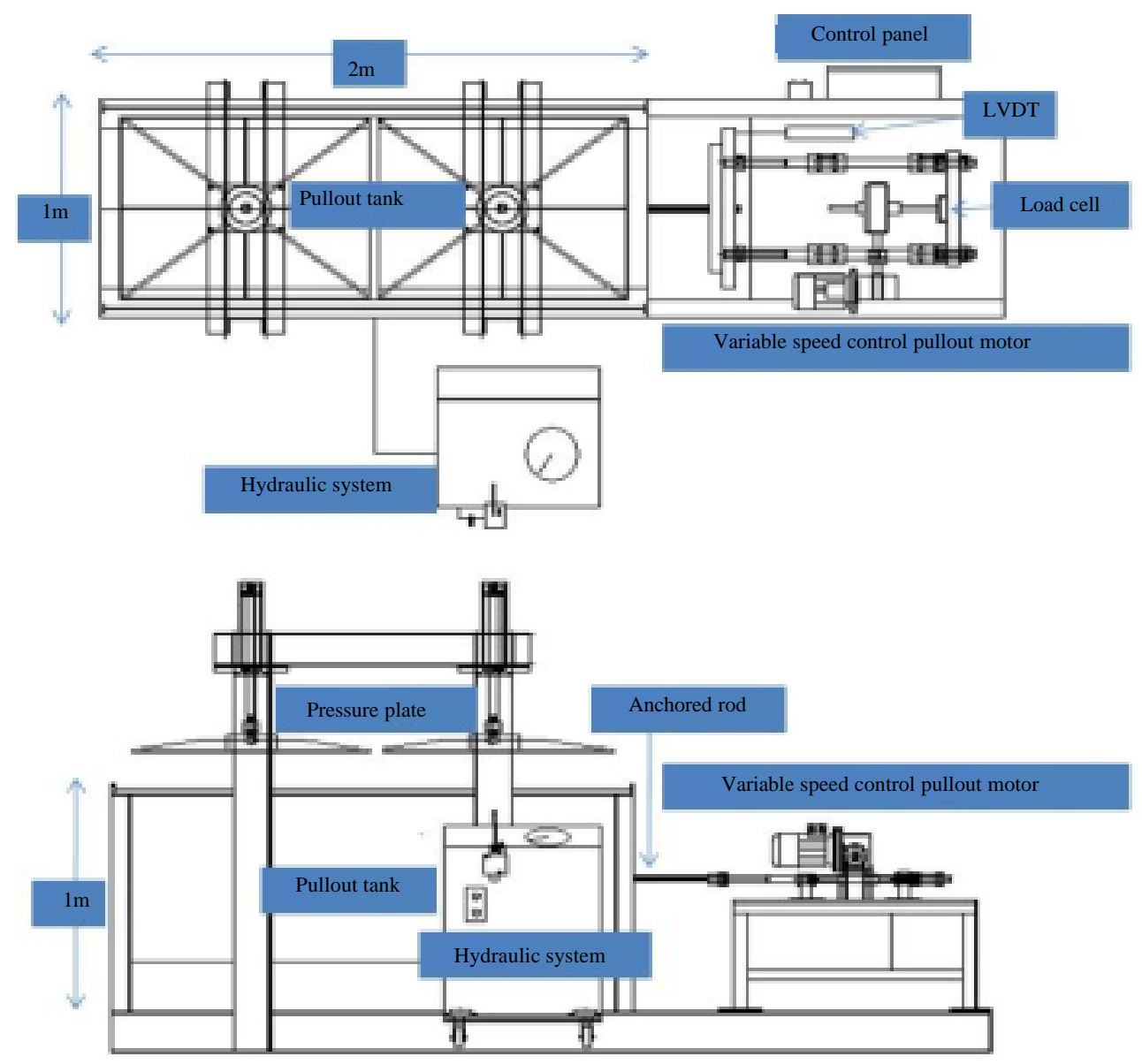

Fig. 13: The schematic diagrams of a pullout test system

four different of vertical loadings of 50,100, 200 and 300 $\mathrm{kPa}$, respectively were done which consists of total 28 numbers of tests. The load cell and LVDT have gone through calibration procedures. The LVDT type is SDP-200D with the capacity of $200 \mathrm{~mm}$ and the serial number is BAJ08038. The calibration coefficient is 0.02 and the $R^{2}$ value is 1 . The load cell series/part number is PNC710-50KLBTL-149. The serial number is 092799 with load range is $0-50000 \mathrm{Lb}$. The $\mathrm{R}^{2}$ is 0.9991 .

Universal Testing Machine (UTM-500) was used to calibrate the load cell. The calibration of the LVDT was measured by gauge block set supplied by Mitutoyo Corporation. Figure 13 shows the set of gauge block. This Mitutoyo gauge block set comprises 33 steel block set included block $2.005 \mathrm{~mm}$ by step $0.01,2.01-2.09 \mathrm{~mm}$ by 0.1 steps, $2.1-2.9 \mathrm{~mm}$ by 1 step and $10-30,60,100 \mathrm{~mm}$ by 10 steps. The calibration analysis of LVDT and load cell data are interpreted in the form of graph which produce the linear equation. The result was key in to the data logging system before proceed with the testing.

\section{RESULTS AND DISCUSSION}

The pullout apparatus was designed to withstand any uplift despite that it was not anchored to the floor by ensuring that there is no eccentricity of the reinforcement. This and the rigidity of the supporting beams have been proved, since, there is no single uplift noticed while running the pullout tests. The testing program has been designed to evaluate the soil-reinforcement interlock capacity by means of pullout testing. Several pullout tests were conducted. The pullout tests were conducted on granular material, silica sand. It has been tested for a dry, $1,2,6$ and $12 \%$, fully saturated and reinforcement without anchor block. The summary of pullout test results with various moisture content and effective/net stresses are shown in Table 2.

Upon the understanding there is drastic drop in the pullout strength when the soil is being wetted (i.e., inundated or infiltrated), therefore, the reinforced soil wall system need to be protected from excessive infiltration to 
Table 2: The summary of pullout tests result with different moisture content under effective/net stress

Maximum pullout force $(\mathrm{kN})$

\begin{tabular}{lrrrrrr}
$\begin{array}{l}\text { Dry with } \\
\text { anchor }\end{array}$ & $\begin{array}{r}\text { anchor } \\
\text { anch }\end{array}$ & $\begin{array}{r}\text { anchor } \\
\text { anc }\end{array}$ & anchor & $\begin{array}{r}\text { anchor } \\
\text { anch }\end{array}$ & $\begin{array}{c}\text { Saturated } \\
\text { with anchor }\end{array}$ & $\begin{array}{c}\text { Saturated } \\
\text { non-anchor }\end{array}$ \\
\hline 86.95 & 121.4 & 123.32 & 115.44 & 84.92 & 82 & 2.1 \\
108.4 & 133.6 & 135.62 & 126.92 & 108.76 & 105.6 & 4.12 \\
112.89 & 137 & 141.3 & 130.6 & 112.1 & 109.6 & 7.01 \\
118 & 150.2 & 154.8 & 141.35 & 115.45 & 110.2 & 10.5 \\
\hline
\end{tabular}

Test series with different moisture content (\%), Effective/net stress (kPa), $50,100,200,300 \mathrm{kPa}$

avoid the loss in suction. This also substantiates the need of the anchor block to ensure the stability of the reinforced soil wall system in case of unexpected excessive infiltration or inundation.

Seven series of test with different moisture content from dry, $1,2,6$ and $12 \%$, saturated and saturated without anchor block under four different effective/net stresses of $50,100,200$ and $300 \mathrm{kPa}$, respectively consisted of 28 pullout tests were involved in this study. The maximum pullout force obviously governs by the applied effective/net stress which increases as the effective/net stress increases. It can be seen that under the same effective/net stress, the maximum pullout force performance increase from dry backfill material to $1 \%$ moisture content of backfill material and peak at $2 \%$ moisture content of backfill material.

The pullout force increases with moisture content up to residual suction (i.e., moisture of $2 \%$ ) and decreases as moisture content increases beyond $2 \%$. This is in compliance with the shear strength behaviour of the test soil which is maximum at residual suction of $10 \mathrm{kPa}$ which correspond to a maximum apparent shear strength of $30 \mathrm{kN} / \mathrm{m}^{2}$.

It requires a quite significant strain to be mobilized in order to achieve a high pullout force for the test at low effective stress. However, for tests at effective stresses of $100 \mathrm{kPa}$ and higher, the high pullout force is mobilized almost immediately upon stressing. As for the non-anchored pullout test series, the performances of the maximum pullout force were also influenced by the applied effective stress. Compared with an anchored pullout test series under various effective stress of 50,100, 200 and $300 \mathrm{kPa}$, the maximum pullout force for the non-anchored pullout test only achieved $2.6,3.9,6.4$ and $9.5 \%$ of the maximum pullout force for an anchored pullout test series, respectively. The massive drop in the pullout strength can be observed when the system is without anchor block.

From the results, the maximum pullout force were peak at $2 \%$ moisture content of backfill material under the $300 \mathrm{kPa}$ net stress giving the maximum pullout force of $154.8 \mathrm{kN}$. This highest performance were governs by the influence of suction presence in the tested backfill material as were determined by the soil-water characteristic curve, SWCC and the curvi-linear Mohr Coulomb envelopes that the residual suction is at $2 \%$ moisture content of backfill material. It is proven that the residual suction occurs at this point and gives highest shear strength value. According to BS8006 (1995), the ultimate pullout resistance of an anchor element in the jth layer may be determined from:

$$
\begin{gathered}
P_{u j}=P_{s j}+P_{a j} \\
P_{s j}=2 \mathrm{mB}_{s} s_{v j}^{\prime} L_{e j} \\
P_{a j}=4 \mathrm{~K}_{p} B_{a} t_{a} s_{v j}^{\prime}
\end{gathered}
$$

Where:

$\mathrm{P}_{\mathrm{s}}=$ The shaft or loop resistance developed by friction beyond the potential failure plane, at the jth layer of anchors

$\mathrm{P}_{\mathrm{a} j}=$ The bearing resistance at the jth layer of anchors

$\mathrm{m}=$ The coefficient of soil/reinforcement friction and is determined according to the relationship given in clause 6.6.4.2.2

$\mathrm{B}_{\mathrm{s}}=$ The long term horizontal projection area of shaft or loop

$\mathrm{K}_{\mathrm{p}}=$ The horizontal passive Earth pressure coefficient

$\mathrm{B}_{\mathrm{a}}=$ The long term width of anchor head

$\mathrm{t}_{\mathrm{a}}=$ The long term height of anchor head

$\mathrm{s}^{\prime}{ }_{\mathrm{vj}}=$ The vertical applied pressure at the jth layer of anchors

$\mathrm{L}_{\mathrm{ej}}=$ The length of the anchor shaft beyond the potential failure plane

By equating the results from the experimental works of this study into Eq. 1-3 according to BS8006 (1995) the theoretical values of maximum pullout force are tabulated and plotted for Table 3 and 4, Fig. 14 and 15.

Table 3 and Fig. 14, the experimental data gives higher values of maximum pullout force (i.e., 82 and 105.6 $\mathrm{kN}$ ) at the lower stress conditions (i.e., at 50 and $100 \mathrm{kPa}$ ) compared to the theoretical values according to BS 8006 (i.e., 29.14 and $58.27 \mathrm{kN}$ ) calculated using Eq. 1-3. At the high stress conditions (i.e., 200 and $300 \mathrm{kPa}$ ), the experimental data gives a lower values (i.e., 109.6 and $110.2 \mathrm{kN}$ ) compared to the theoretical values (i.e., 116.55 and $174.82 \mathrm{kN}$ ). The variations between the experimental data and the theoretical results are due to the variations of internal angle of friction which is higher at low stress level (i.e., $33^{\circ}$ ) and becomes lower at the high stress level (i.e., $30^{\circ}$ ). 
Table 3: Comparison between experimental and theoretical pullout force Maximum pullout force $(\mathrm{kN})$

\begin{tabular}{|c|c|c|c|c|c|c|c|c|}
\hline $\begin{array}{l}\text { Dry with } \\
\text { anchor } \\
\text { (Shaft+Anchor) } \\
\end{array}$ & $\begin{array}{l}1 \% \text { with } \\
\text { anchor } \\
\text { (Shaft+ Anchor) }\end{array}$ & $\begin{array}{l}2 \% \text { with } \\
\text { anchor } \\
\text { (Shaft+Anchor) }\end{array}$ & $\begin{array}{l}6 \% \text { with } \\
\text { anchor } \\
\text { (Shaft+Anchor) }\end{array}$ & $\begin{array}{l}12 \% \text { with } \\
\text { anchor } \\
\text { (Shaft+Anchor) }\end{array}$ & $\begin{array}{l}\text { Saturated } \\
\text { with anchor } \\
\text { (Shaft+Anchor) }\end{array}$ & $\begin{array}{l}\text { Saturated } \\
\text { non-anchor } \\
\text { (Shaft only) }\end{array}$ & $\begin{array}{l}\text { Theoretical (BS8006) } \\
\text { (Shaft+Anchor) } \\
\left(\mathrm{P}_{\mathrm{uj}}\right) \mathrm{f}^{\prime}=33^{\circ}\end{array}$ & $\begin{array}{l}\text { Theoretical (BS8006) } \\
\text { (Shaft+Anchor) } \\
\left(\mathrm{P}_{\mathrm{wi}}\right) \mathrm{f}^{\prime}=30^{\circ}\end{array}$ \\
\hline 86.95 & 121.4 & 123.32 & 115.44 & 84.92 & 82 & 2.1 & $\begin{array}{l}P_{u j} 29.14\left(P_{s j} \text { shaft } 1.99\right. \\
\left.P_{s j} \text { anchor } 27.15\right)\end{array}$ & $\begin{array}{l}P_{u j} 25.80\left(P_{s j} \text { shaft } 1.80\right. \\
\left.P_{a j} \text { anchor } 24.00\right)\end{array}$ \\
\hline 108.4 & 133.6 & 135.62 & 126.92 & 108.76 & 105.6 & 4.12 & $\begin{array}{l}P_{u j} 58.27\left(P_{s j} \text { shaft } 3.99\right. \\
\left.P_{a j} \text { anchor } 54.28\right)\end{array}$ & $\begin{array}{l}P_{u j} 51.60\left(P_{s j} \text { shaft } 3.60\right. \\
\left.P_{a j} \text { anchor } 48.00\right)\end{array}$ \\
\hline 112.89 & 137 & 141.3 & 130.6 & 112.1 & 109.6 & 7.01 & $\begin{array}{l}\mathrm{P}_{\mathrm{uj}} 116.55\left(\mathrm{P}_{\mathrm{sj}} \text { shaft } 7.99\right. \\
\left.\mathrm{P}_{\mathrm{aj}} \text { anchor } 108.56\right)\end{array}$ & $\begin{array}{l}P_{u j} 103.21\left(P_{s j} \text { shaft } 7.21\right. \\
\left.P_{a j} \text { anchor } 96.00\right)\end{array}$ \\
\hline 118 & 150.2 & 154.8 & 141.35 & 115.45 & 110.2 & 10.5 & $\begin{array}{l}\mathrm{P}_{\mathrm{uj}} 174.82\left(\mathrm{P}_{\mathrm{s}} \text { shaft }\right. \\
\left.11.99, \mathrm{P}_{\mathrm{aj}} \text { anchor } 162.83\right)\end{array}$ & $\begin{array}{l}P_{u j} 154.81\left(P_{s j} \text { shaft } 10.81,\right. \\
\left.P_{a j} \text { anchor } 144.00\right)\end{array}$ \\
\hline
\end{tabular}

Test series with different moisture content (\%), Effective/net stress (kPa), 50, 100, 200, 300 kPa

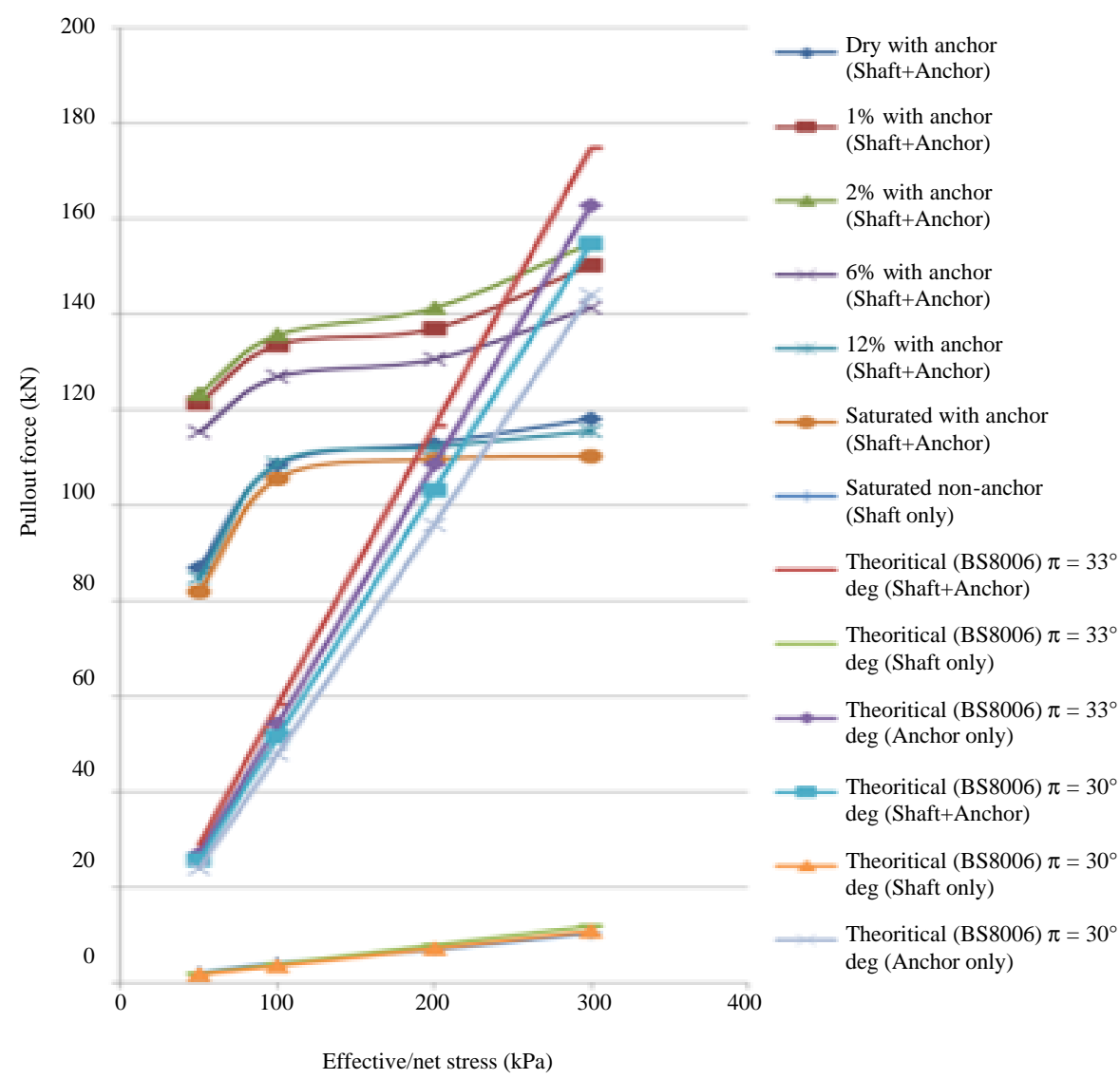

Fig. 14: Comparison between experimental and theoretical pullout force versus effective/net stress

The significance contribution of anchor block under saturated condition can be seen clearly from Table 3 and Fig. 14 and 15. Theoretical lengths of shaft and anchor contribution are shown in Fig. 15. Non-anchored shafts of about $22 \mathrm{~m}$ length need to be provided in order to give an equivalent pullout force of an anchored with 1.5 $\mathrm{m}$ length of shaft. Sample of calculation for the value of bearing resistance of anchor based on Eq. 3 are as follows:

$$
\begin{gathered}
\mathrm{P}_{\mathrm{a}}=4 \mathrm{~K}_{\mathrm{p}} \mathrm{B}_{\mathrm{a}} \mathrm{t}_{\mathrm{a}} \mathrm{s}_{\mathrm{v}}=4\left(1+\sin 33^{\circ} / 1-\sin 33^{\circ}\right)(0.2 \mathrm{~m}) \\
(0.2 \mathrm{~m})\left(300 \mathrm{kPa} \text { or } \mathrm{kN} / \mathrm{m}^{2}\right)=162.83 \mathrm{kN}
\end{gathered}
$$

The above calculation is based on the effective stress of $300 \mathrm{kPa}$ or $\mathrm{kN} / \mathrm{m}^{2}$, internal angle of friction of $33^{\circ}$ and the anchor block dimensions of $0.2 \mathrm{~m}$ width $\times 0.2 \mathrm{~m}$ height $\times 0.1 \mathrm{~m}$ thick. According to BS8006 (1995) the value of $m=\tan d$ where $d$ is angle of friction between the reinforcement material and the soil. As per practice, the 


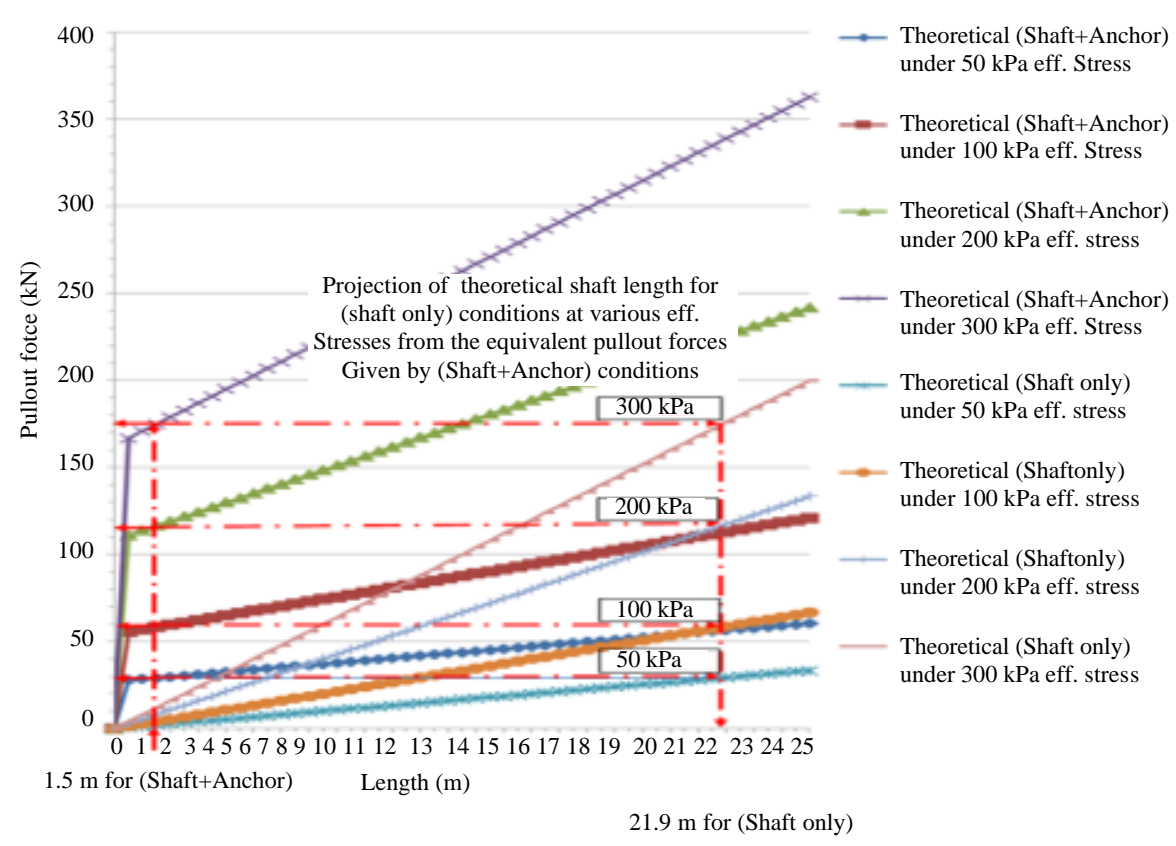

Fig. 15: Projection of theoretical shaft length and anchor contribution

Table 4: The value of the coefficient of soil/reinforcement friction ( $\mathrm{m}$ )

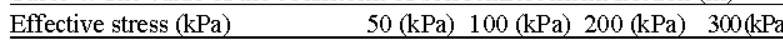

The value of the coefficient of 0.40

soil/reinforcement friction $(\mu)$

(BS8006)

$\begin{array}{lllll}\text { The value of the coefficient of } & 0.42 & 0.42 & 0.35 & 0.35\end{array}$ soil/reinforcement friction, $(\mu)$

based on the pullout test

value of $\mathrm{d}$ is restricted to $2 / 3 \mathrm{f}$, the angle of internal friction of the soil (Chonkar, 2001). Back analysis of the Eq. 2 using the experimental results parameters of this study were done and the value of the coefficient of soil/reinforcement friction, $\mathrm{m}$ according to this particular pullout apparatus and uniformly graded sand backfill material were obtained as tabulated in Table 4. Sample of calculation for the value of coefficient of soil/reinforcement friction, $\mathrm{m}$ based on the experimental pullout test as tabulated in Table 4 is by re-arranging Eq. 2 are as follows:

$$
\mathrm{m}=\mathrm{P}_{\mathrm{s}} / 2 \mathrm{~B}_{\mathrm{s}} \mathrm{s}_{\mathrm{v}}^{\prime} \mathrm{L}_{\mathrm{e} .}=10.5 \mathrm{kN} / 2(0.033 \mathrm{~m})
$$

$\left(300 \mathrm{kPa}\right.$ or $\left.\mathrm{kN} / \mathrm{m}^{2}\right)(1.5 \mathrm{~m})=0.35$

The above calculation is based on the effective stress of $300 \mathrm{kPa}$ or $\mathrm{kN} / \mathrm{m}^{2}$, maximum pullout force of 10.5 $\mathrm{kN}$, shaft diameter of $0.033 \mathrm{~m}$ and effective length of $1.5 \mathrm{~m}$. Figure 6-10 show the comparison between the interpreted linear and curvi-linear envelopes for both saturated and unsaturated conditions. The curvi-linear envelope were fitted to the Mohr's circle and gives the internal angle of friction at low stress level slightly larger than $33^{\circ}$ and gives the value of slightly lower than $33^{\circ}$ (i.e., $30^{\circ}$ ) at the high stress level. It can be seen that the results from this study shows that the curved-surface envelope soil shear strength model manages to make an excellent replication of the true non-linear shear strength behavior (Noor and Anderson, 2006).

The calculations for the maximum pullout force is taking into account the value of angle of friction as 30 and $33^{\circ}$ because from the analysis of shear strength envelope for this study, the value of internal angle of friction from the analysis using curved-surface envelope soil shear strength model was obtained as $30^{\circ}$ whereas the analysis using straight line envelope obtained the angle of friction as $33^{\circ}$ but under cut the Mohr's circle at low stress zones as shown in Fig. 6-10 (Noor and Anderson, 2006).

\section{CONCLUSION}

Conclusion were drawn by analyzing the experimental test results obtained from the study. The pullout apparatus was designed and fabricated. The capability of the apparatus to simulate the wetting condition is proved by the pullout data for the saturated and unsaturated test sand. The soil-water characteristic curve of test sand is shown in Fig. 6. This SWCC is in good agreement with the SWCC for sand reported by Fredlund et al. (1997).

Generally the result of the pullout test in the test sand shows a significant increase in the maximum pullout force 
as suction increases from zero to residual suction at 10 $\mathrm{kPa}$. However, these maximum pullout forces decrease as suction increases from residual suction. These data are presented in Table 2 .

The application of anchor block is very significant in improving the pullout strength when the system is wetted. This is substantiated by the massive drop in the pullout strength when the system is without anchor block. Theoretically, according to Eq. 1-3 from (BS8006, 1995) Fig. 15 shows that it is about 15 times lengthier of shaft are needed to give the equivalent pullout force of an anchor block system if the anchor is to be omitted at any effective stress.

\section{ACKNOWLEDGEMENTS}

This research is fully supported by Fundamental Research Grant Scheme (FRGS) (600-RMI/FRGS 5/3 (73/2015)) and Faculty of Civil Engineering, UiTM Shah Alam. The researchers fully acknowledged Ministry of Higher Education of Malaysia and Universiti Teknologi MARA for the approved fund which makes this important research viable and effective.

\section{REFERENCES}

Antonio, B., 2002. Design of MSE walls for fully saturated conditions. Master Thesis, Purdue University, West Lafayette, Indiana.

BS8006, 1995. Code of practice for strengthened/ reinforced soils and other fills. British Standard Institution, London, UK.

Baharom, B.B. and S.H. Hamzah, 2005. Particle size distribution program. Master Thesis, Faculty of Civil Engineering, Universiti Teknologi MARA, Shah Alam, Malaysia.

Chonkar, R.R., 2001. Review of design of reinforced Earth retaining walls for flyovers. Indian Concr. J., 75 : 782-786.

Christopher, B.R., S. Gill, J.P. Giroud, I. Juran and J.K. Mitchell et al., 1989. Reinforced soil structures Vol 2. summary of research and systems information. Turner-Fairbank Highway Research Center, McLean, Virginia.

Fredlund, M.D., D.G. Fredlund and G.W. Wilson, 1997. Prediction of the soil-water characteristic curve from grain-size distribution and volume-mass properties. Proceedings of the 3rd Brazilian Symposium on Unsaturated Soils, April 22-25, 1997, Rio de Janeiro, Brazil, pp: 13-23.
Ghionna, V.N., N. Moraci and P. Rimoldi, 2001. Experimental Evaluation of the Factors Affecting Pullout Test Results on Geogrids. In: Landmarks in Earth Reinforcement, Ochiai, H., J. Otani, N. Yasufuku and K. Omine (Eds.). CRC Press, Boca Raton, Florida, USA., ISBN:78-9021518633, pp: 31-36.

Hayashi, S., K. Makiuchi and H. Ochiai, 1994. Testing methods for soil-geosynthetic frictional behavior-Japanese standard. Proceedings of the 5th International Conference on Geotextiles, Geomembranes and Related Products Vol. 1, September 5-9, 1994, Kyushu University, Singapore, pp: 411-414.

Izawa, J., Y. Ishihama, J. Kuwano, A Takahashi and H. Kimura, 2001. Effect of Geogrid Properties on Pullout Resistance. In: Landmarks in Earth Reinforcement, Ochiai, H., J. Otani, N. Yasufuku and K. Omine (Eds.). CRC Press, Boca Raton, Florida, USA., ISBN: 78-9021518633, pp 55-60.

Lee, H.S., 2003. The undrained pullout capacity of reinforced soil. Ph.D Thesis, Purdue University, West Lafayette, Indiana.

Lopes, M.L. and M. Ladeira, 1996. Role of specimen geometry, soil height and sleeve length on the pull-out behaviour of geogrids. Geosynthetics Intl., 3: 701-719.

Mak, J.C. and S.R. Lo, 2001. Progressive Failure of Geosynthetic Reinforcement. In: Landmarks in Earth Reinforcement, Ochiai, H., J. Otani, N. Yasufuku and K. Omine (Eds). CRC Press, Boca Raton, Florida, USA., ISBN:78-9021518633, pp: $77-82$.

Noor, M.M. and W.F. Anderson, 2006. A comprehensive shear strength model for saturated and unsaturated soils. Proceedings of the 4th International Conference on Unsaturated Soils 2006, April 2-6, 2006, ASCE, Reston, Virginia, pp: 1992-2003.

Palmeria, E.M. and G.W.E. Milligan, 1989. Scale and other factors affecting the results of pull-out tests of grids buried in sand. Geotechnique, 39: 511-542.

Terzaghi, K.V., 1936. The shearing resistance of saturated soils and the angle between the planes of shear. Proceedings of the 1st International Conference on Soil Mechanics and Foundation Engineering Vol. 1, June 22-26, 1936, Harvard University Press, Cambridge, Massachusetts, pp: 54-56. 